\title{
Mitsuo Oshimura
}

\section{Reply to the letter of Kayashima et al.}

We apprehended that the discrepancy of results generated by the two groups (Kashiwagi et al., 2003; Kayashima et al., 2003) regarding the imprinting analysis of Atp10a/Atp10c in normal adult mice can be caused by the differences of mouse strain, age, brain region, the primers used for cDNA synthesis (random 6 mer or oligo dT) and the primers used for RT-PCR. However, in this report, the only condition that is different applied by the two groups for this imprinting analysis is the use of different strains of mice. Thus, we agree that the most feasible explanation for the discrepancy is the strain background-dependent imprinting (as this report states). There are studies that can support this idea, such as the different imprinting status of mouse Kvlqt1 gene between strain backgrounds (Jiang et al., 1998) and the different phenotypes of the $N d n$ KO mice between strain backgrounds (Gerard et al., 1999; Tsai et al., 1999).

\section{References}

Gerard M, Hernandez L, Wevrick R, Stewart CL (1999) Disruption of the mouse Necdin gene results in early post-natal lethality. Nat Genet 23:199-202

Jiang S, Hemann MA, Lee MP, Feinberg AP (1998) Straindependent developmental relaxation of imprinting of an endogenous mouse gene, Kvlqt1. Genomics 53:395-399

Kashiwagi A, Meguro M, Hoshiya H, Haruta M, Ishino F, Shibahara T, Oshimura M (2003) Predominant maternal expression of the mouse Atp10c in hippocampus and olfactory bulb. J Hum Genet 48:194-198

Kayashima T, Yamasaki K, Joh K, Yamada T, Ohta T, Yoshiura K, Matsumoto N, Nakane Y, Mukai T, Niikawa N, Kishino T (2003) Atp10a, the mouse ortholog of the human imprinted $A T P 10 A$ gene, escapes genomic imprinting. Genomics 81:644647

Tsai TF, Armstrong D, Beaudet AL(1999) Necdin-deficient mice do not show lethality or the obesity and infertility of PraderWilli syndrome. Nat Genet 22:15-16
This reply refers to the letter http://dx.doi.org/10.1007/s10038-0030061-z

M. Oshimura

Department of Biomedical Science,

Institute of Regenerative Medicine and Biofunction,

Graduate School of Medical Science,

Tottori University, 86 Nishimachi, Yonago,

Tottori 683-8503, Japan

E-mail: oshimura@grape.med.tottori-u.ac.jp

Tel.: + 81-859-348260

Fax: $+81-859-348134$ 